\title{
Buddhist Nationalism as Social Movement in Political Transition: MaBaTha Movement in Myanmar
}

\author{
ZHANG Lei \\ Peking University, Beijing, China
}

\begin{abstract}
Aggressive Buddhist nationalism has emerged as a considerable societal issue in Myanmar and a threat to peaceful coexistence in this multi-religious and multi-ethnic country since the political transition. The paper argues that the integration of strong religious capacity and strong political needs is the main reason for the rapid development of Buddhist nationalism in Myanmar since 2011. To be specific, strong religious capacity provides possibilities, and strong political needs create the necessity for the rapid development of Buddhist nationalism. Taking the MaBaTha movement as an example, the paper concludes the developing trajectory and characteristics of the movement. In terms of strong religious capability of Buddhism, the authority and legitimacy of Buddhism in Myanmar lay the foundation for the emergence and expansion of MaBaTha; on the other hand, powerful social network of Buddhism and the extensive community service provided by Buddhist organizations makes MaBaTha have strong mobilization capabilities. In terms of strong domestic political needs, the economic and social realities during the period of political transition made MaBaTha's claims be widely accepted in Myanmar, and political elites' mobilization form was the driving force for the organization's rapid development. Finally, four suggestions are put forward on how to tackle the challenges brought by Buddhist nationalism in Myanmar.
\end{abstract}

Keyword: Buddhist nationalism, Myanmar, social movement, MaBaTha

\section{Introduction}

The tension between ethnic groups in Myanmar has not been eased by political transition from 2011; instead, Buddhist nationalism has rapidly risen and spread since the rape and murder of a Buddhist woman by Muslim men in Rakhine on May 2012. According to the report by International Crisis Group, the intensity and scope of the conflicts and communal violence between Buddhist and Muslim communities has increased in most areas of Myanmar, including Rakhine, Naypyidaw, Rangoon, Bago, Mandalay, Shan, and Sagaing (International Crisis Group, 2013). Many see a connection between these violent episodes and the rise of new Buddhist networks and organizations (Walton \& Hayward, 2014). Especially, a social movement organization called "Association for the Protection of Race and Religion" (commonly referred to by its Burmese-language acronym, MaBaTha) is prominent, which emerged in late 2012 and grew into a national-wide network of monks and laypersons. If the outbreaks of communal violence across the country marked by religious difference keep developing and uncontrolled, it will not only influence Myanmar's diplomacy and state image, but also threaten to derail Myanmar's once-promising transition.

ZHANG Lei, Ph.D. candidate, School of International Studies, Peking University, Beijing, China. 
Why this phenomenon happens in the light of political openness and democratization in Myanmar? The paper aims to explain the reasons why Buddhist nationalism has rapidly spread since 2011. The theory hypothesis and brief history of the dynamics of Buddhist nationalism in Myanmar will be discussed, followed by the detailed analysis on MaBaTha example.

\section{Definition and Literature Review}

Talking about the definition of religious nationalism, efforts to come up with a universal definition of religious nationalism have been unsuccessful. Carlton J. H. Hayes (1926) and Mark Juergensmeyer (1993) argue that religious nationalism is a kind of social and political thought and movement with religion and nationalism as ideology. Barbara-Ann Reiffer (2003) argues that religious nationalism refers to the situation where religion and nationalism are inseparable, and Phillips Barker (2009) pointed out that religion's role in national identity defines religious nationalism. Steve Bruce (2003) and Roger Brubaker (2012) have tried to explain different relationships between religion and nationalism. Atalia Omer and Jason Springs (2013) argue that religious nationalism is the situation when political and religious objectives are conflated and interwoven. In general, there are two category of definition: The first refers to the situation where religion and nationalism are inseparable, and the second category is "instrumental pious nationalism" where religion is part of nationalism but it is not the primary part. As one type of religious nationalism, Buddhist nationalism is defined as a kind of nationalism with Buddhism as ideology and instrument in this paper.

Based on a large amount of interview in fieldwork, International Crisis Group $(2013$; 2017) released two reports describing in detail the fact of Buddhist extremist violence and Buddhist politicization in Myanmar. The reports point out that Buddhist nationalism has emerged as a considerable societal issue in Myanmar and a threat to peaceful coexistence in this multi-religious and multi-ethnic country. Understanding and addressing how these dynamics fuel fear, nationalist rhetoric and militant behaviour within Myanmar's different communities has taken on even greater urgency. Authors such as Ian Holliday (2010), Mary Kate Long (2013), and Maung Zarni (2013) have been giving much importance to the tension between Muslim minorities and the Buddhist majority. Other authors, such as Tessa Bartholomeusz (2002), Michael Jerryson and Mark Jurgensmeyer (2010) have engaged in the analysis of Buddhism as an originator of violence and conflict. It is worth to note that Matthew J. Walton and Susan Hayward (2014) challenge the claim that the recent violence between Buddhists and Muslims is inevitable rooted in communalism. They argues that the current monastic political mobilization can be seen as an extension of past anti-colonial movements and it is rooted in traditional roles of the monastic community to defend the religion, respond to community needs, and guide political decision-makers with the rapid changes in politics and society. Min Lwin Htet (2016) reveals how the movement was initiated, how it reached the stage of a countrywide network, how it managed to influence politics and to promulgate four sets of laws. Moreover, he argues that the monks perceive political opportunities, with the political democracy in Myanmar. Zhong Xiaoxin (2017) and Song Shaojun (2017) illustrate that the increasingly narrow nationalism in Myanmar's political transition is the core motive force for Myanmar's Buddhist extremism. In general, current research mainly focus on empirical research in history and religious studies, however, political, social, and economic factors should not be ignored, besides religious and historical factors. 


\section{Theoretical Hypotheses}

Since the start of the political transition in 2011, Myanmar has been troubled by an upsurge in extreme Buddhist nationalism, anti-Muslim hate speech, and deadly communal violence, not only in Rakhine State but also across the country. The most prominent Buddhist nationalism organization is MaBaTha. In the following part, the author will first propose the theory hypothesis and analyse the interactions between religious capacity and political needs in Myanmar's history, and how the interaction influences on the dynamics of religious nationalism.

The emergence and development of religious nationalism in today's society is not determined by a single factor, but is the result of the interaction of multiple factors. Among them, the interaction between religious capacity and political needs is core factor. The stronger the religious capacity and political needs of a country are, the more religious nationalism it is likely to generate. In light of this, this paper can states my expectations on the interactions between religious capacity and political needs as the following hypothesis (Table 1):

Hypothesis 1 (H1): With strong religious capacity of Buddhism and strong domestic political needs, Buddhist nationalism is more likely to flourish in Myanmar.

Hypothesis 2 (H2): With weak religious capacity of Buddhism and strong domestic political needs, Buddhist nationalism is less likely to flourish in Myanmar, and secular nationalism is more likely to generate.

Hypothesis 3 (H3): With strong religious capacity of Buddhism and weak domestic political needs, Buddhist nationalism is less likely to generate in Myanmar, which religious boundaries and political boundaries are relatively parallel.

Hypothesis 4 (H4): With weak religious capacity of Buddhism and weak domestic political needs, it is unlikely to generate Buddhist nationalism in Myanmar.

Table 1

Theory Hypothesis: Religious Capacity, Political Needs, and Religious Nationalism

\begin{tabular}{|l|l|l|}
\hline Political needs & Seligious capacity & Weak \\
\hline Strong & Religious nationalism & Secular nationalism \\
\hline Weak & Apolitical religion & No religious nationalism \\
\hline
\end{tabular}

That is to say, on one hand, strong traditional religious capacity of Buddhism provides possibilities for the rapid development of Buddhist nationalism in Myanmar. On the other hand, strong domestic political needs create the necessity for the rapid development of Buddhist nationalism in Myanmar.

\section{Dynamic of Religious Capacity and Political Needs in History of Myanmar}

The following part will analyse the dynamic of Buddhist religious capacity, domestic political needs, and religious nationalism since the end of 19th century and the beginning of 20th century in Myanmar (see Table 2). Dating back to the Bagan Dynasty, the first unified feudal dynasty in the history of Myanmar, Buddhism was established as the state religion, monks and Buddhists played an important supporting role in maintaining the feudal rule of the dynasties of Burma (Song, 2017, p. 142). In modern times, the process of British colonialists invading Burma was almost synchronous with the process of Western Christian culture infiltrating Burmese traditional society (Song, 1996, p. 71). In this context, the fights against colonialism were naturally combined with the preservation of Buddhist orthodoxy. From the end of the 19th century to the beginning of the 20th 
century, many nationalist Buddhist research groups emerged throughout Myanmar. Buddhism mobilized the masses in the nationalist movement and promoted large-scale nationalist mass movement, providing a strong cohesive force for anti-British colonial (Tarling, 1992, p. 95). During this period, strong traditional religious capacity of the Buddhism and strong domestic political needs for anti-British colonial rule provide the possibility and necessity for the rapid development of Buddhist nationalism in Myanmar. That is to say, the Buddhist nationalism, which mainly urged for independent and anti-colonialism, emerged in this period.

Buddhism became more secular after Burma's independence, and the 1947 Constitution claimed the special status of Buddhism. Buddhists have been pushing for Buddhism becoming state religion, and promoting Buddhism as a symbol of Myanmar's return to national independence (Ikuno, 1982, p. 71). In 1961, Myanmar Parliament passed the "Constitution Amendment", which made Buddhism the national religion. However, this has intensified the antagonism among some ethnic minorities, especially between Muslims and Buddhists. In September of the same year, focusing on the fourth revision of the constitution, this kind of confrontation became increasingly apparent, destabilizing the political situation, and providing an excuse for the Coup by $\mathrm{Ne}$ Win. After taking office, he abolished the Buddhism as state religion in constitution and implemented a strict policy of "separation religion from government" (Ikuno, 1982, p. 73). Under the harsh religious and ethnic management system, Myanmar's Buddhist religious capacity was weaker than before, and the political needs for anti-colonist and independence were weaker as well; Buddhist nationalist organizations and movements gradually disappeared in Myanmar.

The great unrest in Myanmar in 1988 ended with the coup of the Tatmadaw in September 1988. During the junta-ruling period, poor performance of government led to more doubt on its political legitimacy, so the military government intentionally promoted Buddhist revolutionary movement, and Buddhism as a political rhetoric was used to obtain political legitimacy. On one hand, the military Junta highlighted the growing "threat of otherness" within Myanmar. On the other hand, the Junta has tried to portray itself as the only saviour to protect Buddhism from the threat of others (Zhong, 2017, p. 45). For the most threatening competitor, the NLD led by Aung San Suu Kyi, the military government has repeatedly declared that there were a large number of Muslims infiltrating into the NLD, so voting for the NLD would be a destruction of Buddhism. During this period, religious capacity of Buddhism gradually recovered and Buddhism was used to consolidate the domination and mobilization. That is, Buddhism gradually integrated into various political affairs of Myanmar once again, which laid the seeds for the outbreak of Buddhist nationalism in Myanmar during the political transition.

After the presidential elections in February 2011, the State Peace and Development Council (SPDC) handed over power to the new government led by U Thein Sein, which represents the beginning of political transition in Myanmar. Since then, ethnic and religious conflicts, which were forcibly suppressed under the military government, have resurfaced. At the same time, monks and politics are increasingly integrated, and Buddhist nationalism has begun to reappear in Myanmar (Khin, 2016, p. 24). It is common to see monks actively participate in political activities across the country, including rural politics, national legislation and elections. Since then, Buddhism quickly restored its strong traditional religious capacity in Myanmar. At the same time, how to integrate multiple ethnic groups of different backgrounds and construct a pluralist political awareness and cultural concept is the core issue faced by Myanmar in the process of political transition. In fact, most of the anxieties of monastic communities and Buddhist societies stem from the rapid changes of the country and the uncertainties of the future. The needs for a sense of belongings and direction in the rapidly 
changing society have collided with the anxieties caused by economic reforms. Therefore, there were strong political needs in Myanmar, which integrated with strong religious capacity of Buddhism and made Buddhist nationalism re-flourish.

Table 2

Myanmar's Religious Capacity, Political Needs, and Buddhist Nationalism at Different Times in History

\begin{tabular}{llll}
\hline Time & Variables & $\begin{array}{l}\text { Religious capacity of Buddhism Domestic political needs in } \\
\text { in Myanmar }\end{array}$ & $\begin{array}{l}\text { Muddhist nationalism in } \\
\text { Myanmar }\end{array}$ \\
\hline $\begin{array}{l}\text { Late } 19 \text { and early } 20 \\
\text { century } \sim 1948\end{array}$ & Relatively strong & Strong & Flourishing \\
$1948 \sim 1962$ & Relatively strong & Relatively strong & Declining \\
$1962 \sim 1988$ & Relatively strong & Relatively strong & Disappearing \\
$1988 \sim 2011$ & Relatively strong & Relatively strong & Recovering \\
Since 2011 & Strong & Strong & Flourishing \\
\hline
\end{tabular}

\section{The Development of MaBaTha}

The above part has analysed the dynamics of Buddhist religious capacity and domestic political needs in Myanmar since the end of the 19th century to illustrate the research hypothesis. In the following part, Association for the Protection of Race and Religion (MaBaTha) will be discussed in detail, including its structure, activities, and evolution, followed by the reasons why it has been developing so fast since political transition from 2011 based on the research hypothesis.

Although more institutionalized than the 969 movement, MaBaTha, which established in June 2013 and covered more than 220 townships in Myanmar, has a highly decentralized structure based around a group of monasteries, monks, and laypersons (International Crisis Group, 2017, p. 17). Centring on the central committee that situated within Yangon's Insein Ywama Monastery, the organization structure of MaBaTha is like an umbrella. However, the central committee has limited authority over regional branches and personalities, and there is no a shared accounting system, with funds being handled by individual monasteries and members, so this amorphous structure makes it difficult to enforce any ban (International Crisis Group, 2017, pp. 18-19). The development stages of MaBaTha can be divided into the following four stages:

\section{Stage 1 (June 2013 to January 2014): Emergence and Growth}

The first meeting was held and initial mobilization tasks were distributed to the original members on June 2013. At this stage, the USDP and the NLD has not noticed MaBaTha, and the organization was mainly engaged in extensive mobilization and increasing influence, with little social movement.

\section{Stage 2 (January 2014 to 2016): Extensive Political Participation}

MaBaTha launched a nationwide campaign to struggle for enacting the four laws, including population control law (passed in May 2015), the Buddhist Women's Special Marriage Law (passed in August 2015), the Religious Conversion Law (passed in August 2015), and the Monogamy Law (passed in August 2015), in addition, holding public conference and public protest in Mandalay, Naypyidaw, and Yangon (Walton \& Hayward, 2014, p. 16). In May 2014, MaBaTha opposed the signature campaign for constitutional reforms, which were mainly targeted at Article 436 about the provision for constitutional amendments and Article 59 that forbad Aung San Suu Kyi to be eligible as a presidential candidate (Htet, 2016, pp. 49-50). However, an alliance of civil society organizations issued a statement strongly opposing the proposed laws, claiming that 
violated rights of women and minorities (Shwe \& Feliz, 2014). MaBaTha responded quickly with a statement calling the civil society groups "traitors on national affairs" and disputing their claims to represent Burmese communities because they are supported by foreign groups (Nyein, 2014). At this stage, MaBaTha tends to support USDP in public and the minister of religious affairs visited key members of the group for several times (Htet, 2016, p. 52).

\section{Stage 3 (2016 to May 2017): Widely Involved in Conflicts and Violence}

Some members from MaBaTha vigorously protested an aid shipment for Rakhine state sent by the Malaysian government (International Crisis Group, 2017, p. 16). The investigation into assassination of Ko Ni, who was a Muslim legal advisor of NLD, considered MaBaTha involvement. In addition, communal tensions rose in neighbourhoods of Yangon with large Muslim populations, and violent nationalist protests demanded local authorities shut down two Muslim schools that doubled as prayer centres (International Crisis Group, 2017, p. 16). Nationalists also insisted that police raid an apartment they alleged to be a safe house for illegal Muslim migrants (implied to be Rohingya from Rakhine State); the mob turned violent when the raid uncovered no evidence (International Crisis Group, 2017, p. 16). At this stage, MaBaTha's branches covered most areas of Myanmar, with strong social network and mobilization capacity. In addition, the organization integrated more with politics, and its behaviours combined social movements with complex political needs, becoming a political force that cannot be underestimated in Myanmar.

\section{Stage 4 (Since May 2017): Restricted and Dormant}

Before MaBaTha's planned four-year anniversary, the Sangha Council issued a new statement on May 23 2017, indicating more clearly that MaBaTha was in violation of the Sangha Law. The statement banned using of the MaBaTha name and logo and requiring all MaBaTha signs and placards to be removed by 15 July. Therefore, the planned fourth anniversary celebration on May 27 and 28 had to be cancelled, and headquarter of MaBaTha announced that it would abide by the statement. However, the majority of branched refused to obey. On July 15, the government led by NLD warned the members through state media, who still did not abide by the Sangha council's statement, that the government would sue those who rejected. Since then, MaBaTha and its supporters appeared to have temporarily halted most activities, but this should be interpreted more as a regrouping than a defeat (International Crisis Group, 2017, p. 18).

\section{Reasons for Rapid Development of MaBaTha Since 2011}

The paper argues that strong traditional religious capacity of Buddhism provides possibilities for the rapid development of Buddhist nationalism in Myanmar. On the other hand, strong domestic political needs create the necessity for the rapid development of Buddhist nationalism in Myanmar. Specifically, strong religious capacity of Buddhism and strong domestic political needs since 2011 are illustrated in the following four perspectives.

\section{Strong Religious Capacity of Buddhism Since 2011}

On one hand, the authority and legitimacy of Buddhism in Myanmar lay the foundation for the emergence and expansion of MaBaTha. Although Buddhist doctrines advocate monks and believers to leave the secular world, it is widely accepted in Burmese society that Sangha is symbiotic with the state and that Buddhism has been seen as a panacea for all political cruxes (Than, 2015, p. 12). With political transition in Myanmar, the monks have become more influential in the political mobilization for election. In addition, the ruling party's 
attempts to ban MaBaTha lack legitimacy in Burmese society. In July 2016, the statement of the Sangha Council stated that MaBaTha was not a "legal" Buddhist organization, which indicated that MaBaTha has not been formally registered as a monk organization yet. In fact, this will not affect the legitimacy of the organization. Because Burmese Buddhists generally believe that the legitimacy of the religion, which must be obtained by constantly strengthening the religion and its followers' activities, is different from the Sangha Council's executive power empowered by government according to law. Therefore, in the eyes of many Burmese Buddhists, MaBaTha and its chief monks are more legitimate than what the Sangha Council is. The monks in the organization use their authority as community leaders to influence secular believers, which makes MaBaTha attractive and appealing in Burmese society.

On the other hand, the powerful social network of Buddhism in Myanmar and the extensive community service provided by Buddhist organizations provide strong mobilization capabilities. With the political transition, the media regulation in Myanmar has been increasingly relaxed, besides traditional preach, monks have made full use of paper and online media to mobilized, which has largely strengthened the social mobilization capacity and propaganda efficiency of the Buddhist system. In addition, by providing elementary education, law aids, disputes resolution, disaster relief, and protection of women's rights, MaBaTha's intensive community service has strengthened its authority and mobilization capacity at the grassroots level (International Crisis Group, 2017, pp. 20-22). Especially in remote areas where the government power is weak, MaBaTha has filled the gap left by the government's longstanding ineffective governance. It is worth to note that MaBaTha's women supporters are not limited to poorly educated and rural women, but include members of the country's most prestigious nunneries, respected female religious scholars and lay lawyers, educators, and medical professionals, who see the organization as a platform to improve the situation of women around the country (International Crisis Group, 2017, p. 22). What's more, with its religious legitimacy, extensive social support and a nationwide network, MaBaTha provides an effective platform for upper-class people to achieve their goals. For example, a female MaBaTha council member indicated that she joined MaBaTha because she wanted to raise money for schools in Rakhine State, and the group was happy to give her a platform for a series of religious talks through which she raised several hundred dollars in three days. This led her to deepen her engagement with MaBaTha, having concluded it provided a better opportunity for supporting her community than the NLD, of which she was an early member and strong supporter (International Crisis Group, 2017, p. 23).

\section{Strong Domestic Political Needs Since 2011}

On one hand, the economic and social realities during the period of political transition have made MaBaTha's claims widely accepted in Myanmar. The dictatorship for many years commonly caused pent-up frustration and anger of the Burmese people, and the development of the telecommunications industry and the media has accelerated the spread opinions. In this context, civilian are easily infected by Buddhist nationalist speech and preach. Both "969 movement" and MaBaTha are calling for protection ethnic and religious purity in Myanmar, defending the divine sovereignty of the Union of Myanmar, safeguarding national resources, not colonized by the great powers, and constraining the expansion of Islam in Myanmar (Kyaw, 2016, p. 183). Actually, these appeals existed since Myanmar's independence, but Burmese people's long-pressed frustrations and anger were broke out in forms of Buddhist nationalism since the political transition from 2011. Facing the needs for spiritual leading and belongs, Buddhist nationalist organizations represented by MaBaTha provide a 
sense of prestige, belonging, and direction for individuals, especially young individuals in a rapidly changing society in Myanmar. Although Myanmar's poverty rates fell from 44.5\% in 2004 to $26.1 \%$ in 2015, the poverty rates remain in a high level, especially in rural areas (World Bank Website). By 2017, 29\% of children under five years old under are malnourished, $60 \%-70 \%$ of children drop out of school, and only a third of the population have access to electricity from the state grid (World Bank Website). These realities and the sense of economic anxiety that ordinary people do not actually benefit from reforms provide space for the popular and explosive growth of religious nationalism.

On the other hand, the guidance and mobilization form of Myanmar's political elite is the driving forces for the rapid development of Buddhist nationalism (Khin, 2016, p. 26). Since Myanmar's political transition, the political elites of two parties have competed for the support of MaBaTha in order to win the election, so political elites intended to ignore and connive the rapid development of MaBaTha. The officials of USDP and the NLD have both donated money to subordinate monasteries of MaBaTha, and monks in MaBaTha have close personal relationships with most of political parties. On one hand, political elites wanted to use MaBaTha to conduct social mobilization in order to win votes, leading to the rapid development of these Buddhist nationalist organizations and realization of their appeals. Even after the NLD achieving an overwhelming victory in the 2015 election, government has only issued a statement through the Sangha Council that bans $\mathrm{MaBaTha}$ to use its name and post slogans in public, considering its extensive social support network and influence on voters supporting NLD. The NLD worried that there would be serious reaction across the country to affect the stability of Myanmar's society and the implementation of economic reforms, if government toughly repressed and sanctioned the organization (International Crisis Group, 2017, p. 27). On the other hand, MaBaTha also took advantage of the competition of political elites to expand their space for development. Before the 2015 elections, headquarter of MaBaTha tactfully stated that the organization's goal was to protect the law, not to support a particular party, which attracted both of USDP and NLD's attention (Htet, 2016, p. 51). For USDP, the government of U Thein Sein acquiesced in the rapid growth of the organization and enacted the four laws in May and August 2015. A booklet published and sold at the MaBaTha headquarters declared that probably the promulgation of the laws is a political opportunity opening up for president U Thein Sein (Htet, 2016, p. 52). Wirathu, one of the most famous leading monks in MaBaTha, also said, "I am especially grateful to the president, who has enacted the race and religion protection laws despite international pressure" (Ghosh, 2015). For the NLD, considering a large part of its supporters coming from MaBaTha, the NLD decided to follow other major parties and not send Muslim candidates to participate in the election under the pressure from voters and rumour about its pro-Muslim standpoint (International Crisis Group, 2017, p. 27).

\section{Conclusion}

Aggressive Buddhist nationalism has emerged as a considerable societal issue in Myanmar and a threat to peaceful coexistence in this multi-religious and multi-ethnic country since the political transition from 2011. The reason why Buddhist nationalism has developed rapidly since the political transition in Myanmar is the integration of strong religious capacity of Buddhism and strong domestic political needs. To be specific, strong traditional religious capacity of Buddhism provides possibilities for the rapid development of Buddhist nationalism. On the other hand, strong domestic political needs create the necessity for the rapid development of Buddhist nationalism. 
Therefore, efforts to tackle Buddhist nationalist organizations like MaBaTha must start from recognition of its sources of support. At the same time, the government should pay more attention to economic and social development to enhance the public's confidence in the future, and improve people's livelihood so that the reform can actually benefit the civilian, in addition, positively influencing and guiding monk' activities. Finally, increase employment opportunities and develop community activities, so that civilian can access to more social networks besides religious network, which will help to enhance social inclusion of diversity and undermine social foundation of religious nationalism organization.

\section{References}

Barker, P. (2009). Religious nationalism in modern Europe: If God be for us. London: Routledge.

Bartholomeusz, T. J. (2002). In Defense of Dharma: Just-War Ideology in Buddhist Sri Lanka. London: Routledge.

Brubaker, R. (2012). Religion and nationalism: Four approaches. Nations and Nationalism, 18(1), 2-20.

Bruce, S. (2003). Politics and religion. New Jersey: John Wiley \& Sons.

Ghosh, N. (2015). Myanmar nationalist monks stages large rally. The Straits Times. Retrieved from http://www.straitstimes.com/asia/se-asia/mynmar-nationalist-monks-stages-large-rally

Guo, J. G. (2014). Religious conflict in Myanmar's transition to democracy. Southeast Asia Studies, 6, 4-9.

Hayes, C. (Ed.). (1926). Essays on nationalism. London: The MacMillan Company.

Holliday, I. (2010). Ethnicity and democratization in Myanmar. Asian Journal of Political Science, 18(2), 111-128.

Htet, M. L. (2016). Politicized religion as social movement in nascent democracy: The MaBaTha movement in Myanmar. Budapest: Central European University.

Huang, X. N. (1992). The revival of modern Myanmar Buddhism and Buddhist nationalism. Southeast Asia Studies, 6, 59-64.

Ikuno, Z. (1982). History of Theravada Buddhism in Burma. Southern Asia, 11, 152-157.

International Crisis Group. (2013). The dark side of transition: Violence against Muslims in Myanmar. Asia Report No. 251.

International Crisis Group. (2017). Buddhism and state power in Myanmar. Asia Report No. 290.

Jerryson, M., \& Juergensmeyer, M. (2010). Buddhist warfare. New York: Oxford University Press.

Juergensmeyer, M. (1993). The new cold war? Religious nationalism confronts the secular state. California: University of California Press.

Jurgensmeyer, M. (2010). The global rise of religious nationalism. Australian Journal of International Affairs, 64(3), $262-273$.

Khin, Z. W. (2016). Buddhism and nationalism: Time for Myanmar to grow beyond its nationalism. Southeast Asia Affairs, 165(1), 24-31.

Kyaw, N. N. (2016). Islamophobia in Buddhist Myanmar: The 969 Movement and Anti-Muslim Violence, in Melissa Crouch ed., Islam and the State in Myanmar. Oxford: Oxford University Press, 183-210.

Li, C. Y. (1997). Buddhism in the modern Burmese democratic movement. Buddhism Studies, 6, 224-236.

Long, M. (2013). Dynamics of state, Sangha and society in Myanmar: A closer look at the Rohingya issue. Asian Journal of Public Affairs, 6(1), 79-94.

Nyein, N. (2014). Nationalist monks call NGOs "traitor" for opposing interfaith marriage bill. The Irrawaddy. Retrieved from https://www.irrawaddy.com/news/burma/nationalist-monks-call-ngos-traitors-opposing-interfaith-marriage.html

Omer, A., \& Springs, J. (2013). Religious nationalism: A reference handbook. California: ABC-CLIO.

Qian, X. M. (2007). A study on religious nationalism. Ethnic Studies, 4, 12-21.

Rieffer, B. (2003). Religion and nationalism: Understanding the consequences of a complex relationship. Ethnicities, 3(2), 215-242.

Shew, A., \& Fwliz, S. (2014). Battle lines drawn on interfaith marriage proposal. Democratic Voice of Burma. Retrieved from http://www.dvb.no/analysis/battle-lines-drawn-on-interfaith-marriage-proposal/40759

Song, L. D. (1996). The development of Buddhist nationalism in south and Southeast Asia. Buddhism Studies, 6, 71-79.

Song, S. J. (2017). The rise, development and characteristics of Burmese Buddhist nationalism and its impact on Myanmar's political transition. South Asia Studies, 1, 137-154.

Tarling, N. (1992). The Cambridge history of Southeast Asia. Cambridge, UK: Cambridge University Press.

Than, T. (2015). Nationalism religion and violence: Old and new Wunthanu Movements in Myanmar. The Review of Faith and International Affairs, 13(4), 12-24. 
Walton, M., \& Hayward, S. (2014). Contesting Buddhist narratives: Democratization, nationalism and communal violence in Myanmar. Hawaii: East-West Center.

Zarni, M. (2013). Buddhist nationalism in Burma. Tricycle. Retrieved from http://www.tricycle.com/feature/buddhist-nationalism-burma?page $=0,0$

Zhang, Y. (2016). Governance dilemma of ethno-religious conflict in post-colonial Myanmar. Southeast Asia Studies, 1, 11-22.

Zhong, X. X. (2017). The historical origin and its contemporary evolution of Buddhist extremism in Myanmar-Tradition worldly engagement, nationalism and political rhetoric. Southeast Asia Studies, 5, 36-47. 